\title{
EFFECT OF CHELATING AGENTS ON PHYTOXICITY AND BIOACCUMULATION OF HEAVY METALS IN VASCULAR PLANTS
}

\author{
MIROSLAV HORNÍK ${ }^{1,2}$, JANA GULDANOVÁ ${ }^{1}$, \\ MARTIN PIPÍŠKA ${ }^{1,2}$, JANA MAREŠOVÁ ${ }^{1}$, JOZEF AUGUSTÍNN ${ }^{1,2}$ \\ ${ }^{I}$ Department of Biotechnology, University of SS. Cyril and Methodius, J. Herdu 2, \\ Trnava, SK-917 01, Slovak Republic (hornikm@ucm.sk) \\ ${ }^{2}$ Consortium for Environmental Biotechnology and Environmental Chemistry, \\ 418 Špačince, 919 51, Slovak Republic
}

\begin{abstract}
In this work the effect of chelating agents ethylenediaminetetraacetate (EDTA) and nitrilotriacetate (NTA) on phytotoxicity and bioaccumulation of $\mathrm{Cd}$ and Co in tobacco plants (Nicotiana tabacum L.) hydroponically grown in diluted Hoagland media (HM) spiked with ${ }^{109} \mathrm{Cd}$ and ${ }^{60} \mathrm{Co}$ was studied. Speciation analysis using a program Visual MINTEQ showed, that the portion of bioavailable ionic $\mathrm{Me}^{2+}$ forms significantly decreased in the presence of EDTA or NTA in $25 \%$ HM for account of $[\mathrm{Me}-\mathrm{EDTA}]^{2-}$ or [Me-NTA] complexes. We found that the equimolar addition of EDTA or NTA to $50 \mu \mathrm{mol} / \mathrm{dm}^{3} \mathrm{CdCl}_{2}$ or $\mathrm{CoCl}_{2}$ in $\mathrm{HM}$ positively diminished phytotoxicity of $\mathrm{Cd}$ or Co on tobacco plants. Bioaccumulation of $\mathrm{Cd}$ by tobacco roots during $8 \mathrm{~d}$ cultivation was minimally affected in the presence of equimolar concentrations of EDTA or NTA to $10 \mu \mathrm{mol} / \mathrm{dm}^{3} \mathrm{CdCl}_{2}$ in media. On the contrary, equimolar concentration of EDTA or NTA added into HM caused considerable decrease of Co uptake by tobacco roots. Cadmium showed higher mobility in conductive tissues of tobacco plants than cobalt and the transport ratio in the presence of EDTA or NTA increased 2-times or 3-times in comparison with control experiments (without addition of chelates), respectively. In the case of cobalt this effect was observed in a less extent. Obtained data suggest the possibilities and constraints in the use of chelating agents in phytoextraction technologies in term of phytotoxicity, uptake and translocation of metals in plant tissues.
\end{abstract}

Key words: cadmium, cobalt, bioaccumulation, phytotoxicity, Nicotiana tabacum, speciation

\section{Introduction}

Heavy metals soil pollution is a serious worldwide problem and can be potentially harmful to human health via the food chain. In most cases, metals soil contamination results from anthropogenic activities such as mining, smelting, fertilizer application, and in the case of radionuclides from typical operations of nuclear fuel cycle, nuclear weapon testing and occasional nuclear disasters.

The stricter implementation of environmental laws urges the development of costeffective soil remediation methods. Traditional techniques of remediation are expensive and may cause secondary pollution. Phytoremediation, the use of green plants to remove pollutants from soil, is one cost-effective method to remediate metal and radionuclide contaminated soils. The technical aspects of phytoremediation are described in numbers of review papers (see latest works in this area e.g. PILONSMITS and LEDUC, 2009; VANGRONSVELD et al., 2009) and monographs (see e.g. MACKOVA et al., 2006; WILLEY, 2007).

Phytoextraction as one of the most perspective phytoremediation method depends mainly on the bioavailability of toxic metals and radionuclides in the soil and the plant 
capacity to accumulate these contaminants. Therefore, some researchers have found that complexing ligands (e.g. EDTA, NTA, EDDS and others) can solubilize the heavy metals with the purpose of making them available for uptake (SALT et al., 1998), but they are not necessarily available for plant uptake (TANDY et al., 2006). They redistribute surface contamination down the soil profile, causing a reduction in the concentration near the soil surface (ROBINSON et al., 2003) and distribute the heavy metals within the entire root zone for uptake. In addition, some authors reported that complexes of Me-chelate were less phytotoxic than free $\mathrm{Me}^{2+}$ forms or protonated chelates (HERNÁNDEZ-ALLICA et al., 2007).

Our previous works studied the bioaccumulation of $\mathrm{Zn}, \mathrm{Co}, \mathrm{Cd}$ or $\mathrm{Cs}$ from nutrient solutions by roots of hydroponically cultivated sunflower (Helianthus annuus L.), tobacco (Nicotiana tabacum L.) and celery (Apium graveolens L.) plants (HORNÍK et al., 2005; HORNÍK et al., 2007; HORNÍK et al., 2008) and radiocesium accumulation from contaminated soil by autochthonous vegetation of plants (PIPÍŠKA et al., 2005). The aim of the current work was to investigate the influence of chelating agents ethylenediaminetetraacetic acid (EDTA) and nitrilotriacetic acid (NTA) on Cd and Co phytotoxicity and bioaccumulation in tissues of hydroponically cultivated tobacco plants (Nicotiana tabacum L.). Bioaccumulation of $\mathrm{Cd}$ and $\mathrm{Co}$ ions in plants was analyzed by gamma-spectrometry using ${ }^{109} \mathrm{Cd}$ and ${ }^{60} \mathrm{Co}$ as radiotracers.

\section{Material and methods}

\subsection{Plant material}

Seeds of tobacco (N. tabacum L.) were germinated and grown in pots filled with granulated perlite as an inert carrier and watered with $25 \%$ strength Hoagland nutrient medium (HOAGLAND, 1920) at light/dark photoperiod 12/12 h (2 $000 \mathrm{~lx})$ and $22^{\circ} \mathrm{C}$. The composition of the full strength $(100 \%)$ nutrient solution was (in $\mathrm{mg} / \mathrm{dm}^{3}$ ) $\mathrm{MgSO}_{4} \cdot 7 \mathrm{H}_{2} \mathrm{O}-370 ; \mathrm{KNO}_{3}-404 ; \mathrm{CaCl}_{2}-444 ; \mathrm{NaH}_{2} \mathrm{PO}_{4} \cdot 2 \mathrm{H}_{2} \mathrm{O}$ - 292; $\mathrm{Na}_{2} \mathrm{HPO}_{4} \cdot 12 \mathrm{H}_{2} \mathrm{O}-46.5 ; \mathrm{FeSO}_{4} \cdot 7 \mathrm{H}_{2} \mathrm{O}-17.9 ; \mathrm{NaNO}_{3}-340 ; \mathrm{NH}_{4} \mathrm{Cl}-214 ; \mathrm{NH}_{4} \mathrm{NO}_{3}-$ $160 ; \mathrm{H}_{3} \mathrm{BO}_{3}-8.5 ; \mathrm{Na}_{2} \mathrm{MoO}_{4} \cdot 2 \mathrm{H}_{2} \mathrm{O}-0.06 ; \mathrm{MnSO}_{4} .5 \mathrm{H}_{2} \mathrm{O}-5.0 ; \mathrm{ZnSO}_{4} .7 \mathrm{H}_{2} \mathrm{O}-0.66$; $\mathrm{CuSO}_{4} .5 \mathrm{H}_{2} \mathrm{O}-0.8(\mathrm{pH}$ 6). After 8 weeks pre-cultivation seedlings were gently removed from perlite and roots were washed free of any adhering perlite granules by deionized water and used in bioaccumulation experiments.

\subsection{Bioaccumulation experiments and cultivation conditions}

Plants from pre-cultivation phase were transferred into vessels with a cover to protect plant roots against lights and cultivated for 8 days in $25 \%$ strength Hoagland medium containing $\mathrm{CdCl}_{2}$ or $\mathrm{CoCl}_{2}$ spiked with ${ }^{109} \mathrm{Cd}$ or ${ }^{60} \mathrm{Co}$. There were two treatments without or with chelating agents EDTA or NTA. The $\mathrm{pH}$ of nutrient solutions was adjusted to 6.0 using $1 \mathrm{M} \mathrm{NaOH}$. Bioaccumulation experiments were carried out in triplicate series at photoperiod $12 / 12 \mathrm{~h}(2000 \mathrm{~lx})$ and $22^{\circ} \mathrm{C}$. In time intervals samples of nutrient solution were taken and ${ }^{109} \mathrm{Cd}$ or ${ }^{60} \mathrm{Co}$ radioactivity was measured by gamma-spectrometry. At the end of the experiments plants were 
harvested, roots were carefully rinsed in deionized water and incorporated radioactivity in roots, stems and leaves was measured. Plant parts were then oven dried (at $60^{\circ} \mathrm{C}$ for 24 hours) and dry weights were determined.

Growth value $(\mathrm{GV})$ was calculated during the experiments as a ratio between $\mathrm{m}(\mathrm{i})$ $-m(t)$ and $m(i)$, where $m(i)$ or $m(t)$ are fresh weight of plants at the start or end of experiments, respectively.

\subsection{Speciation modelling}

For in silico estimations of $\mathrm{Cd}$ and $\mathrm{Co}$ speciation in nutrient solutions as a function of total salt concentration, the presence or absence of chelating agents (EDTA or NTA), solution $\mathrm{pH}$ and temperature were carried out with Visual MINTEQ (version 2.53). This speciation modelling program allows the calculation of complexes [Me-EDTA] or [Me-NTA] portion in cultivation media for specified conditions.

\subsection{Radiometric analysis}

Gamma spectrometric scintillation detectors 54BP54/2-X and 76BP76/3 with well type crystal $\mathrm{NaI}(\mathrm{Tl})$ (Scionix, Netherlands) and data processing software Scintivision32 (Ortec, USA) were used for ${ }^{109} \mathrm{Cd}$ and ${ }^{60} \mathrm{Co}$ determination in plant parts and cultivation media. A library of radionuclides was built by selecting characteristic $\gamma$-ray peaks $\left(88.04 \mathrm{keV}\right.$ for ${ }^{109} \mathrm{Cd}$ and $1173.24 \mathrm{keV}$ or $1332.50 \mathrm{keV}$ for ${ }^{60} \mathrm{Co}$ ) for energy and efficiency calibration. Standardized ${ }^{109} \mathrm{CdCl}_{2}$ and ${ }^{60} \mathrm{CoCl}_{2}$ solutions were obtained from Czech Metrological Institute (Czech Republic).

\section{Results and discussion}

\subsection{Effect of chelating agents on $\mathrm{Cd}$ and Co phytotoxicity}

In our work for calculation of $\mathrm{Cd}$ and $\mathrm{Co}$ ionic forms in nutrient media the program Visual MINTEQ ver. 2.53 we used. However, this evaluation has to be considered with caution, because the modelling program does not include the participation of the plant. Moreover, the high concentrations of EDTA and NTA used here likely also mask the effects of the exudates from the roots. Plant exudates can contribute to changing the $\mathrm{pH}$, the $\mathrm{Eh}$, and the predominant chemical species of the toxins of concern (NIU et al., 2007). Even so, we used the simulation results as a first approximation to the chemical mechanisms in the near-root zone.

We found that in used Hoagland media (HM) at $\mathrm{pH} 6.0$ and $22^{\circ} \mathrm{C}$ more than $95 \%$ of $\mathrm{Co}$ was found as bioavailable $\mathrm{Me}^{2+}$ ions. Only $78 \%$ of $\mathrm{Cd}$ was found in the form of $\mathrm{Cd}^{2+}$ ions, whereby also significant proportion represented ionic $\mathrm{CdCl}^{+}$form $(12.7 \%)$ and $\mathrm{CdHPO}_{4}$ form $(6.4 \%)$. Complexing ligands significantly decreased the concentration of cationic $\mathrm{Co}^{2+}$ or $\mathrm{Cd}^{2+}$ forms and the concentration of $[\mathrm{Me}-\mathrm{EDTA}]^{2-}$ or [Me-NTA] ${ }^{-}$complex forms increased.

For evaluation of $\mathrm{Cd}$ and $\mathrm{Co}$ phytotoxic effect on tobacco plants the calculation of growth value (the ratio of fresh weight of plants at the start or end of experiments 
difference to fresh weight of plants at the start of experiments) and macroand microscopy observation of phytotoxic symptoms on leaves were used.
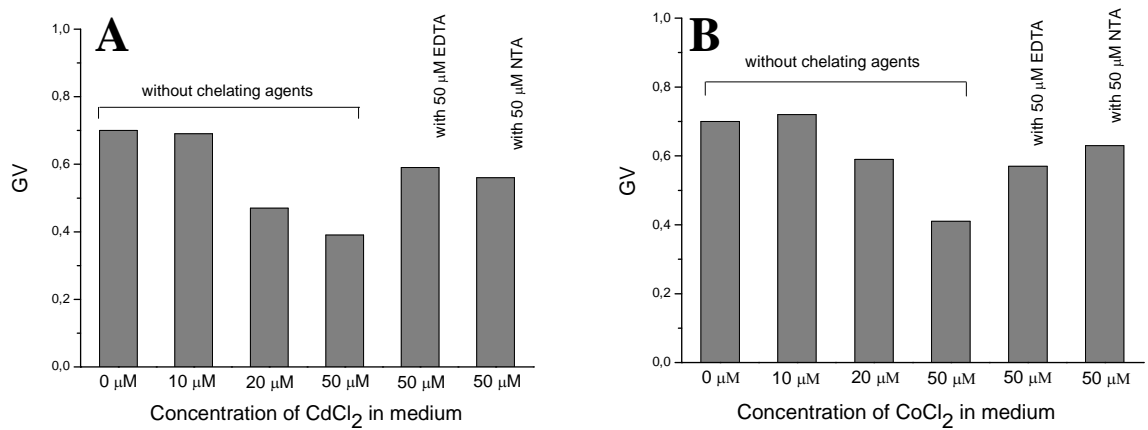

Fig. 1. The evaluation of phytotoxicity effect of $\mathrm{Cd}(\mathrm{A})$ and $\mathrm{Co}(\mathrm{B})$ on the basis of growth value (GV) of tobacco plants (N. tabacum L.) after $8 \mathrm{~d}$ cultivation in $25 \% \mathrm{HM}$ without or with addition of EDTA or NTA at illumination 12/12 day/night period $(2000 \mathrm{~lx}), \mathrm{pH} 6.0$ and $22^{\circ} \mathrm{C}$.

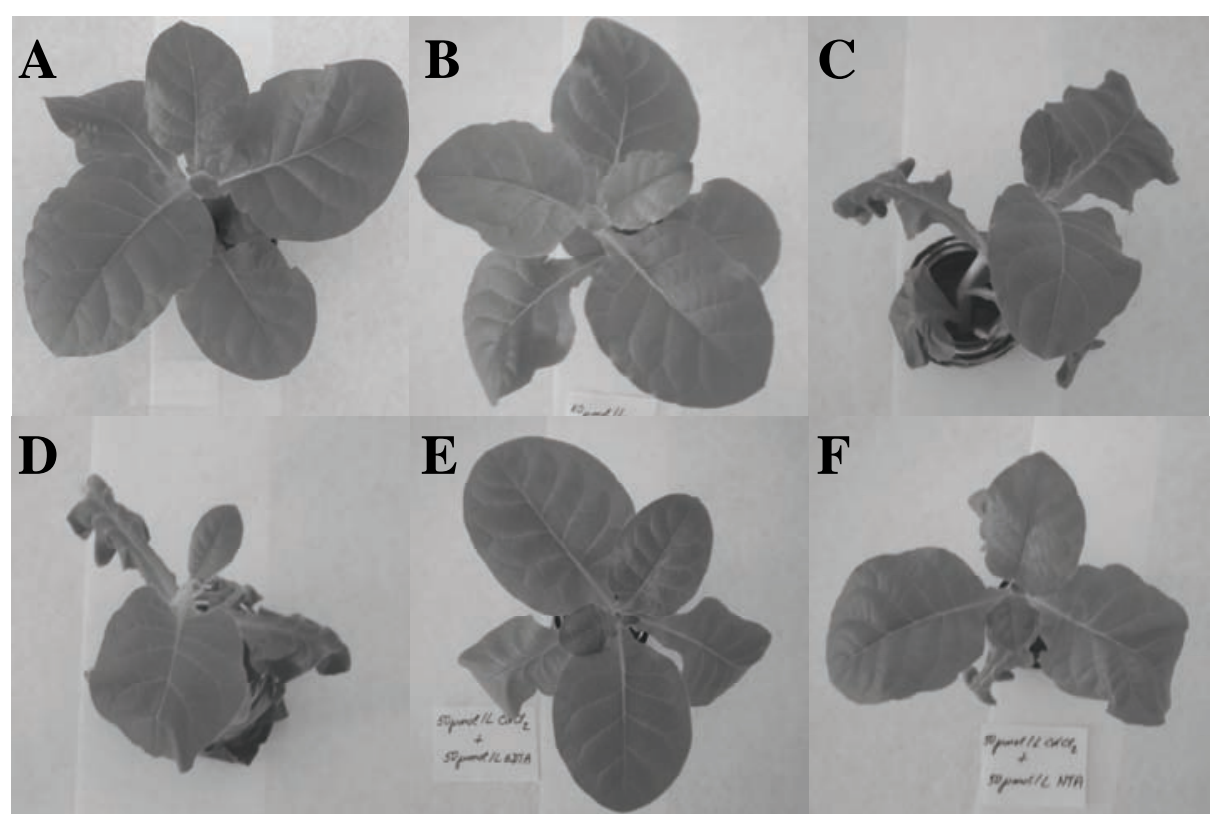

Fig. 2. Phytotoxicity effect of cadmium (die-back of leaves) in tobacco plants (N. tabacum L.) after $8 \mathrm{~d}$ cultivation at illumination 12/12 day/night period $(2000 \mathrm{~lx}$ ) in $25 \% \mathrm{HM}, \mathrm{pH} 6$ containing: A. $0 \mu \mathrm{mol} / \mathrm{dm}^{3} \mathrm{CdCl}_{2} ;$ B. $10 \mu \mathrm{mol} / \mathrm{dm}^{3} \mathrm{CdCl}_{2} ;$ C. $20 \mu \mathrm{mol} / \mathrm{dm}^{3} \mathrm{CdCl}_{2} ;$ D. $50 \mu \mathrm{mol} / \mathrm{dm}^{3} \mathrm{CdCl}_{2}$; E. $50 \mu \mathrm{mol} / \mathrm{dm}^{3} \mathrm{CdCl}_{2}+50 \mu \mathrm{mol} / \mathrm{dm}^{3}$ EDTA; F. $50 \mu \mathrm{mol} / \mathrm{dm}^{3} \mathrm{CdCl}_{2}+50 \mu \mathrm{mol} / \mathrm{dm}^{3} \mathrm{NTA}$. GV (growth value): A. 0.70 ; B. 0.69 ; C. 0.47 ; D. 0.39; E. 0.59; F. 0.56 .

Fig. 1 shows, that the equimolar addition of EDTA or NTA to $50 \mu \mathrm{mol} / \mathrm{dm}^{3} \mathrm{CdCl}_{2}$ or $\mathrm{CoCl}_{2}$ in Hoagland media positively diminished phytotoxicity effect of $\mathrm{Cd}$ or $\mathrm{Co}$ on tobacco plants growth evaluated on the basis of growth values (GV) calculation. 
Fig. 2 and 3 depict the die-back of plant leaves in the presence of $\mathrm{Cd}$ or chlorosis of leaves in the presence of Co in media as well as the effect of chelating agents on these processes. Phytotoxicity symptoms (die-back of leaves) and lower growth value were observed at 20 or $50 \mu \mathrm{mol} / \mathrm{dm}^{3} \mathrm{CdCl}_{2}$ concentrations in media (Fig. $1 \mathrm{~A}$, 2C, 2D). After $50 \mu \mathrm{mol} / \mathrm{dm}^{3}$ Co-treatment, plants yellowed with typical chlorotic ringspot symptoms and lower growth value than the control were found (Fig. 1B, 3D). Moreover, we found that this Co-treatment used in our experiment had impact on trichomes size and density (Fig. 4A). LEFÈVRE et al. (2009) found that more than $30 \%$ of accumulated $\mathrm{Cd}$ was found at the leaf surface and accumulated in trichomes. On the other side BAKKAUS et al. (2005) reported that cobalt was mainly located around the leaf veins. At the end of the $50 \mu \mathrm{mol} / \mathrm{dm}^{3}$ Cd-treatment or Co-treatment with addition of EDTA or NTA in media, no sign of phytotoxicity was observed (Fig. 2E, 2F, 3E, 3F and 4B).

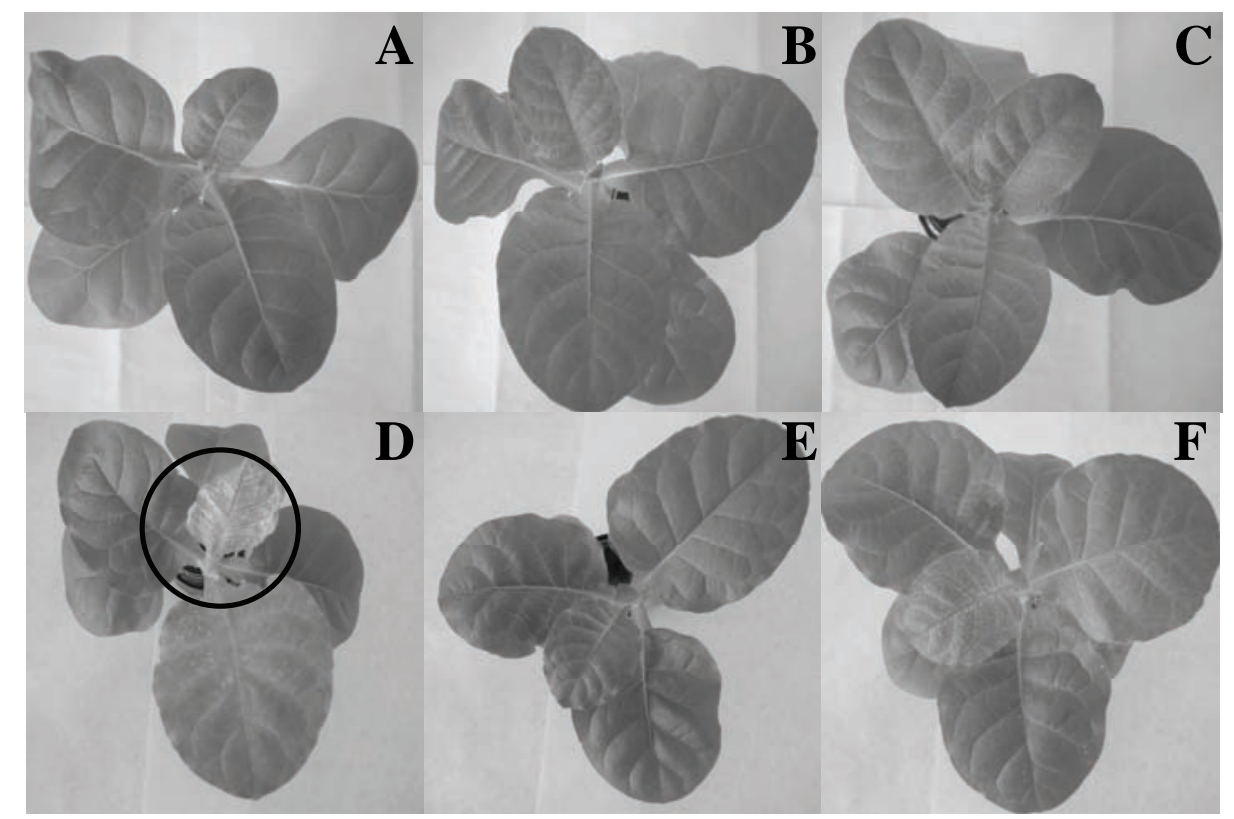

Fig. 3. Phytotoxicity effect of cobalt (chlorosis of leaves) in tobacco (N. tabacum L.) plants after $8 \mathrm{~d}$ cultivation at illumination $12 / 12$ day/night period $(20001 \mathrm{x})$ in $25 \% \mathrm{HM}, \mathrm{pH} 6$ containing: A. $0 \mu \mathrm{mol} / \mathrm{dm}^{3} \mathrm{CoCl}_{2}$; B. $10 \mu \mathrm{mol} / \mathrm{dm}^{3} \mathrm{CoCl}_{2} ;$ C. $20 \mu \mathrm{mol} / \mathrm{dm}^{3} \mathrm{CoCl}_{2} ;$ D. $50 \mu \mathrm{mol} / \mathrm{dm}^{3} \mathrm{CoCl}_{2}$; E. $50 \mu \mathrm{mol} / \mathrm{dm}^{3} \mathrm{CoCl}_{2}+50 \mu \mathrm{mol} / \mathrm{dm}^{3}$ EDTA; F. $50 \mu \mathrm{mol} / \mathrm{dm}^{3} \mathrm{CoCl}_{2}+50 \mu \mathrm{mol} / \mathrm{dm}^{3} \mathrm{NTA}$. GV (growth value): A. 0.70 ; B. 0.72 ; C. 0.59 ; D. 0.41 ; E. 0.57 ; F. 0.63 .

We suggest that the decrease of metal concentration in $\mathrm{Me}^{2+}$ form caused by chelating agents in nutrient media and the formation of [Me-ligand] complexes in media could diminish phytotoxic effect. Similar effect was also found by others authors (see e.g. HERNÁNDEZ-ALLICA et al., 2007). This fact could be helpful in phytoremediation of contaminated soils with high concentration of toxic metals, where most plants can not grow under normal conditions. 


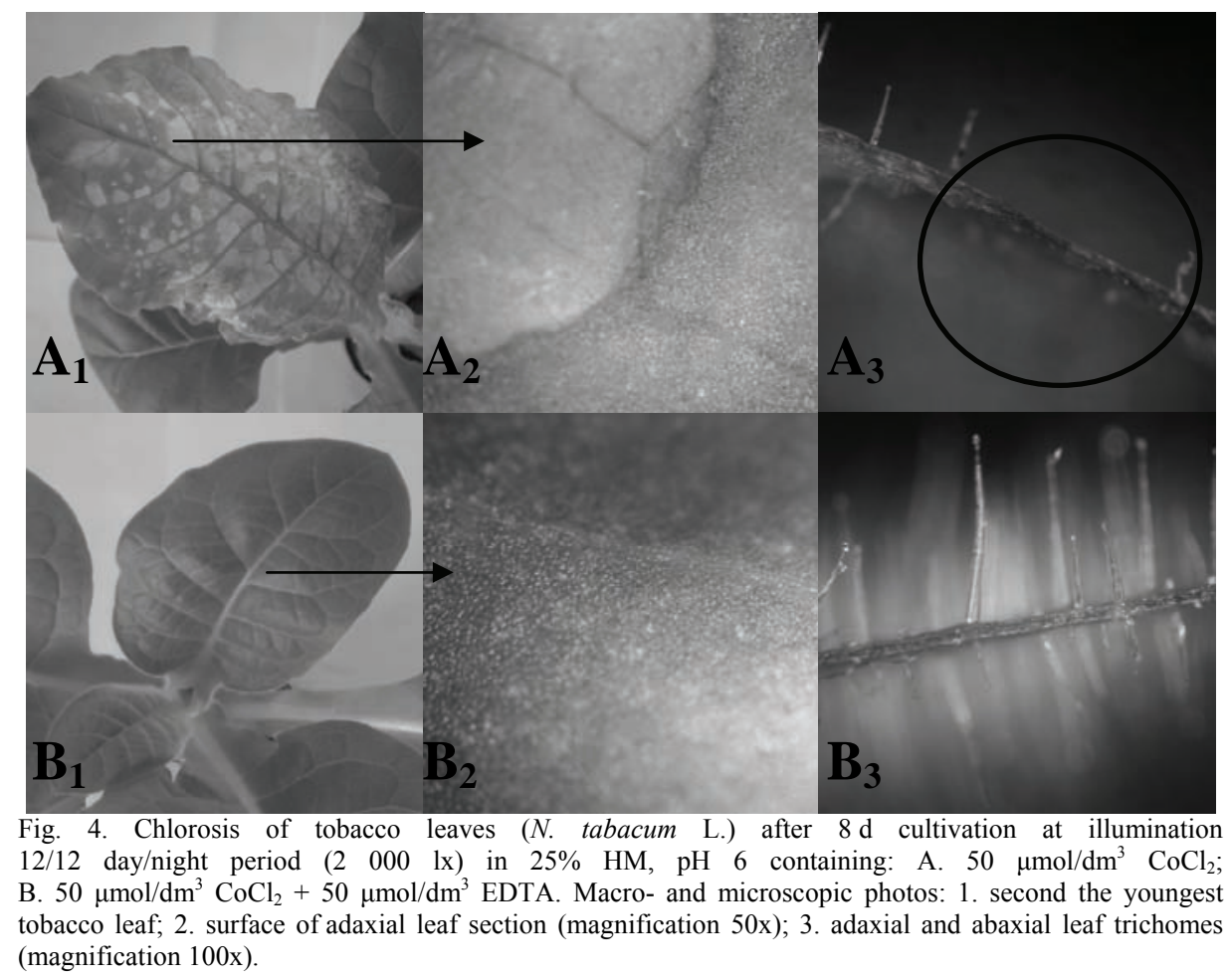

\subsection{Effect of chelating agents on Cd and Co bioaccumulation}

Bioaccumulation of $\mathrm{Cd}$ by tobacco roots during $8 \mathrm{~d}$ cultivation was minimally affected in the presence of EDTA or NTA equimolar concentrations to $10 \mu \mathrm{mol} / \mathrm{dm}^{3}$ $\mathrm{CdCl}_{2}$ in media. On the contrary, equimolar concentration of EDTA or NTA added into Hoagland media caused considerable decrease of Co uptake by tobacco roots (Fig. 5A). Calculated speciation of $\mathrm{Cd}$ and $\mathrm{Co}$ in used Hoagland medium (HM) is depicted in Fig. 5B.

For evaluation of metals mobility in conductive tissues of plants in the term of metal translocation efficiency we established non-dimensional transport ratio $(T R)$, which represent the ratio of metal concentration in aboveground part of plants $[\mathrm{Me}]_{\text {shoot }}$ to metal concentration in root system of plants $[\mathrm{Me}]_{\text {root }}$ Cadmium showed higher mobility in conductive tissues of tobacco plants than cobalt and the transport ratio in the presence of EDTA or NTA increased 2-times or 3-times in comparison with control experiments (without addition of chelates), respectively (Fig. 6). In the case of cobalt this effect was observed in a less extent. Some authors reported that metal uptake is related to the availability of metals in soils and the addition of natural and/or synthetic chelators into soil could increase uptake and translocation of metals (see e.g. QUARTACCI et al. (2007). However, the amendment with non-biodegradable chelants of high metal-binding capacity, the high persistence of chelates and their 
potential leaching to groundwater pose severe environmental concerns connected with the use of synthetic chelating agents such as EDTA and its derivatives. QUARTACCI et al. (2007) found that NTA and mainly EDDS were high effective in enhancing the concentrations of $\mathrm{Cd}, \mathrm{Cu}, \mathrm{Pb}$ and $\mathrm{Zn}$ in Brassica carinata shoots.
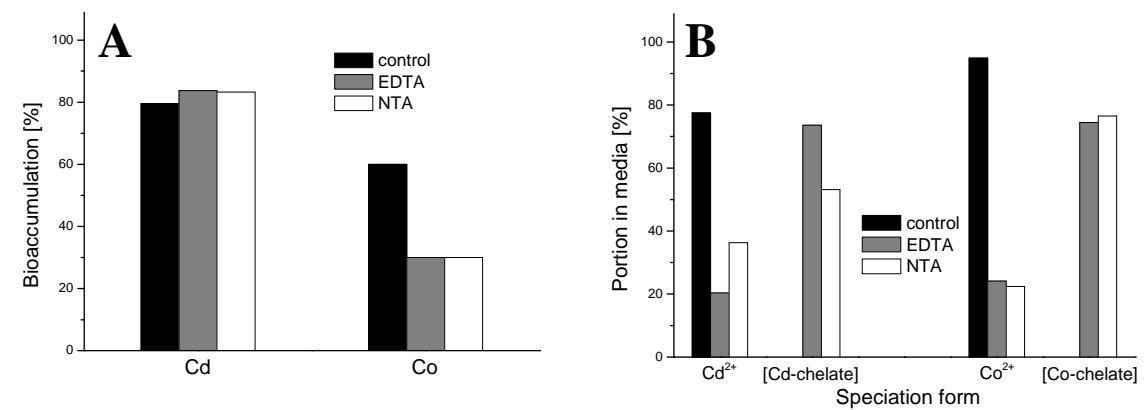

Fig. 5. A. Effect of EDTA and NTA on Cd and Co uptake by tobacco roots ( N. tabacum L.). Data after $8 \mathrm{~d}$ cultivation at $22^{\circ} \mathrm{C}$ and illumination $12 / 12$ day/night period $(2000 \mathrm{~lx})$ in $25 \% \mathrm{HM} \mathrm{pH} 6.0$ containing $10 \mu \mathrm{mol} / \mathrm{dm}^{3} \mathrm{CoCl}_{2}$ or $10 \mu \mathrm{mol} / \mathrm{dm}^{3} \mathrm{CdCl}_{2}$ and equimolar EDTA or NTA. B. Portion of $\mathrm{Me}^{2+}\left(\mathrm{Cd}^{2+}\right.$ or $\left.\mathrm{Co}^{2+}\right)$ and [Me-chelate] ([Me-EDTA $]^{2-}$ or [Me-NTA $\left.]^{-}\right)$forms in cultivation media at $22^{\circ} \mathrm{C}$ and $\mathrm{pH}$ 6.0. Speciation of Cd and Co was calculated by program Visual MINTEQ ver. 2.53

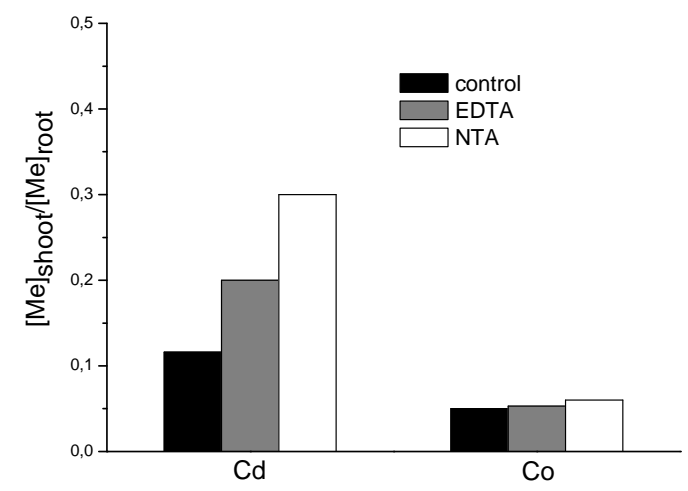

Fig. 6. Effect of EDTA and NTA on translocation of $\mathrm{Cd}$ and Co from roots to shoots (TR) of tobacco (N. tabacum L.) after $8 \mathrm{~d}$ plant cultivation in $25 \% \mathrm{HM}$ containing $10 \mu \mathrm{mol} / \mathrm{dm}^{3} \mathrm{MeCl}_{2}(\mathrm{Me}=\mathrm{Cd}$ or Co) without or with equimolar addition of EDTA or NTA, pH 6.0 at illumination 12/12 day/night period (2000 lx) and $22^{\circ} \mathrm{C}$.

\section{Conclusions}

The results from hydroponic cultivation of tobacco plants (N. tabacum) indicate that chelating agents (EDTA and NTA) are able to decrease of $\mathrm{Cd}$ and $\mathrm{Co}$ phytotoxicity, and on the other side these agents can increase of metal translocation from roots to shoots of tobacco plants. This fact can positively affect all processes involved in phytoremediation of contaminated environment with toxic metals or radionuclides. 


\section{References}

BAKKaUs, E., GOUGET, B., GALliEN, J.-P., KHODJA, H., CARROT, F., MOREL, J.L., COLLINS, R.: Concentration and distribution of cobalt in higher plants: The use of micro-PIXE spectroscopy. Nucl. Instrum. Methods Phys. Res. B, 231, 2005, 350-356.

HERNÁNDEZ-ALLICA, J., GARBISU, C., BARRUTIA, O., BECERRIL, J.M.: EDTA-induced heavy metal accumulation and phytotoxicity in cardoon plants. Environ. Exp. Bot., 60, 2007, s. 26-32.

HOAGLAND, D.R.: Optimum nutrient solution for plants. Science, 52, 1920, 562564.

HORNÍK, M., PIPÍŠKA, M., SEKÁČOVÁ, J., AUGUSTÍN, J.: Determination of long distance transport of $\mathrm{Cs}^{+}, \mathrm{Co}^{2+}$ and $\mathrm{Zn}^{2+}$ ions in vascular plants by autoradiography and gamma-spectrometry. Nova Biotechnol., VII-1, 2007, 33-40.

HORNÍK, M., PIPÍŠKA, M., VRTOCH, L., SEKÁČOVÁ, J., AUGUSTÍN, J., LESNÝ, J.: Influence of complexing ligands on $\mathrm{Zn}$ uptake and translocation in tobacco and celery plants. Acta Agronomica Ovariensis, 2008, 50, 65-71.

HORNÍK, M., PIPÍŠKA, M., VRTOCH, L., AUGUSTÍN, J., LESNÝ, J.: Bioaccumulation of ${ }^{137} \mathrm{Cs}$ and ${ }^{60} \mathrm{Co}$ by Helianthus annuus. Nukleonika, 50, 2005, S49-S52.

LEFĖVRE, I., MARCHAL, G., MEERTS, P., CORRÉAL, E., LUTTS, S.: Chloride salinity reduces cadmium accumulation by the Mediterranean halophyte species Atriplex halimus L. Environ. Exp. Bot., 65, 2009, 142-152.

MACKOVA, M., DOWLING, D., MACEK, T.: Phytoremediation Rhizoremediation. Springer, Dordrecht, The Netherlands, 2006, 300 pp.

NIU, Z.X., SUN, L.N., SUN, T.H., LI, Y.S., WANG, H.: Evaluation of phytoextracting cadmium and lead by sunflower, ricinus, alfalfa and mustard in hydroponic culture. J. Environ. Sci., 19, 2007, 961-967.

PILON-SMITS, E.A.H., LEDUC, D.L.: Phytoremediation of selenium using transgenic plants. Curr. Opin. Biotechnol., 20, 2009, 207-212.

PIPÍŠKA, M., HORNÍK, M, LESNÝ, J., AUGUSTÍN, J.: Transfer rádiocézia ${ }^{137} \mathrm{Cs}$ z kontaminovanej neobrábanej pôdy do vol’ne rastúcej vegetácie. Agriculture (Pol'nohospodárstvo), 51, 2005, 470-478.

QUARTACCI, M.F., IRTELLI, B., BAKER, A.J.M., NAVARI-IZZO, F.: The use of NTA and EDDS for enhanced phytoextraction of metals from a multiply contaminated soil by Brassica carinata. Chemosphere, 68, 2007, 1920-1928.

SALT, D.E., SMITH, R.D., RASKIN, I.: Phytoremediation. Annu. Rev. Plant Physiol. Plant Mol. Biol., 49, 1998, 643-668.

VANGRONSVELD, J., HERZIG, R., WEYENS, N., BOULET, J., ADRIAENSEN, K., RUTTENS, A., THEWYS, T., VASSILEV, A., MEERS, E., NEHNEVAJOVA, E., VAN DER LELIE, D., MENCH, M.: Phytoremediation of contaminated soils and groundwater: lessons from the field. Environ. Sci. Poll. Res., (in press).

WILLEY, N.: Phytoremediation. Methods and Reviews. Humana Press, New Jersey, USA, 2007, 478 pp. 